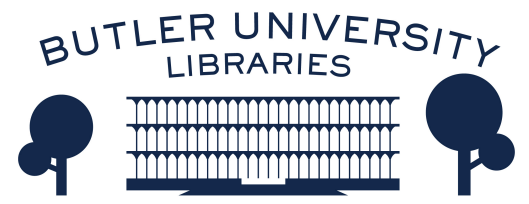

Journal of Hindu-Christian Studies

Volume 31 Celebrating Rāmānuja at 1000: The

Heritage and Promise of the Study of Rāmānuja

in a Christian-Hindu Comparative Theology

Article 21

2018

\title{
Act Properly: Rāmānuja and Luther on Works
}

Rakesh Peter Dass

Hope College

Follow this and additional works at: https://digitalcommons.butler.edu/jhcs

\section{Recommended Citation}

Dass, Rakesh Peter (2018) "Act Properly: Rāmānuja and Luther on Works," Journal of Hindu-Christian Studies: Vol. 31, Article 21.

Available at: https://doi.org/10.7825/2164-6279.1698

The Journal of Hindu-Christian Studies is a publication of the Society for Hindu-Christian Studies. The digital version is made available by Digital Commons @ Butler University. For questions about the Journal or the Society, please contact cbauman@butler.edu. For more information about Digital Commons @ Butler University, please contact digitalscholarship@butler.edu. 


\title{
Act Properly: Rāmānuja and Luther on Works
}

\author{
Rakesh Peter Dass \\ Hope College
}

\begin{abstract}
: 2017 offered a reason to celebrate and compare two great theologians. In April 2017, Hindus celebrated the 1000th anniversary of Śri Rāmānujācārya. In October, Christians celebrated the 500th anniversary of Luther's reformation. The occasion to compare was also an opportunity to show that the ideas of Rāmānuja and Luther converge in certain ways. This paper explains that Rāmānuja's teachings on proper acts prefigure Luther's commentary on good works. This echo is threefold in nature. First, the idea of merit or reward-inspired actions preoccupied and shaped their respective theologies. second, their teachings on merit reflect a shared interest in placing the work of a gracious God at the center of soteriology. Third, their occupation with the idea of merit inspired them to differentiate good or proper acts from improper acts. I further explain that this convergence is more than an accident. Rather, Luther echoes Rāmānuja on works because both theologians faced a common quandary - what should I do to be saved? - to which their responses were shaped by a shared set of theological commitments. Both asserted the importance of proper acts or good works even as they exhorted a dependence on God for liberation.
\end{abstract}

\section{Introduction}

2017 marked a milestone with the celebration of two great theologians. In April 2017 , Hindus celebrated the $1000^{\text {th }}$ anniversary of Śri Rāmānuja. ${ }^{1}$ In October, Christians celebrated the $500^{\text {th }}$ anniversary of Luther's reformation. In a way, Rāmānuja is to Hindu theology what Luther is to Christian theology. Both teachers brought still-lasting changes and substantial reforms to the dominant theologies of their respective religious traditions. Rāmānuja's qualification of nondualism affirmed an appreciation of the reality of things and inspired the development of a work-concerned devotional theology while Luther's questioning of intermediaries between God and grace reframed Christian notions of salvation and scripture. Both asserted the importance of proper acts or good works even as they exhorted a loving surrender to God. ${ }^{2}$ As I show in this essay, this similarity is more than an accident. Rather, Luther's arguments on good works echo Rāmānuja's arguments on proper works because both theologians were faced with a common quandary - what should I do to be saved? - to which their responses were shaped by a shared set of theological commitments.

Dr. Rakesh Peter Dass studies the role of religion in society, and his research and teaching focus on the intersections of religion with business, language, law and politics. Ongoing projects include manuscripts on language and religion in modern India, Hindi Hindu nationalism and Christianity, and the shaping of religious rights in legal rulings by the Supreme Courts in India and the U.S.A. At Hope College, which he joined in 2016, he teaches courses on world religions, the Bhagavad Gita, business and religion, and Hindu-Christian theology. 
Differently put, Luther can be considered a Christian Rāmānuja. ${ }^{3}$

No work exists that compares Rāmānuja and Luther on works. This paper, and a companion book to follow, address this gap in Hindu and Christian scholarship. While comparative studies of Rāmānuja and Christian sources have addressed topics like grace, ${ }^{4}$ the nature of the world, ${ }^{5}$ incarnation, ${ }^{6}$ philosophy, ${ }^{7}$ metaphysics, ${ }^{8}$ and absolute dependence, ${ }^{9}$ no comparative work has addressed the value of works in the writings of Rāmānuja and Luther.

This essay argues that many of Luther's arguments on good works are prefigured in Rāmānuja's teachings on the means to liberation. To the best of my knowledge, a historical line cannot be sketched from Luther to Rāmānuja in real time. Luther was not reading Rāmānuja, talking to modified nondualists, or pen-palling with sixteenth century Tamil love-poets. Rather, the echo of Rāmānuja's arguments in Luther's proposals is better understood as the result of certain shared theological commitments in response to a common question: what is the place of my actions in God's salvific saga? Luther's echo of Rāmānuja, I show, is threefold in nature. First, the idea of merit or reward-inspired actions preoccupied their respective theologies. Second, their teachings on merit reflect a shared interest in placing the work of a gracious God at the center of soteriology. Third, their occupation with agency and action led them to differentiate proper acts from improper ones, promoting the former over the latter in the face of questions surrounding the salvific value of good works.

\section{Where's the Merit?}

For Rāmānuja and Luther, the idea of merit (or reward-inspired actions) shaped important controversies during their eras. So, for instance, in his Gītā Bhāṣya, Rāmānuja interprets the Gita in ways that promote devotional theology and detached actions as a response to the renunciatory arguments coming from the śramana tradition. "If, in your 'self-conceit'," he writes about Kṛṣna's speech to Arjuna, "you think, 'I will not fight,' then this resolve based on your sense of independence will be in vain." Such a resolve stems from ignorance, Rāmānuja interprets the Gitā to be saying of Arjuna's resolve, because, as Rāmānuja explains, "Nature will compel you to do against your resolve." ${ }^{10}$ In rejecting the renunciation of obligatory actions as an option, Rāmānuja follows not only in the footsteps of his teacher, Yāmuna, but also remains truthful to the Gitā. About the Gìtā's analysis of actions, Surendranath Dasgupta writes, "Prakrti, or the collection of the five factors, moves us to work. That being so, no one can renounce all actions." ${ }^{11}$ Or, as Angelika Malinar suggests in her commentary on the Gitā, the teaching of karma yoga counters the idea of giving up social duties and ritual obligations as an alternative path to liberation. ${ }^{12}$

Rāmānuja's Śrī Bhāṣya and Gìtā Bhāṣya exemplify the argument for the performance of dharma. Dharma has been traditionally understood as prescribed conduct, obligatory actions, or duty. It is a performance of acts according to law or what is right. ${ }^{13}$ R. C. Zaehner translates dharmain the Gitā as 'duty' (see 3:35 and 18:47). So does Swami Ādidevānanda, translator of Rāmānuja's Gìtā Bhâsya (3:35 and 18:47). When translating 4:78, Zaehner and Ādidevānanda interpret dharma as a system of laws. In doing so, they follow in the footsteps of Rāmānuja, who takes dharma to mean duties according to the system of four castes and four stages. Zaehner suggests that Rāmānuja in turn may be taking his cue from Kṛṣna's claim in 4:13 to have been the founder of this system. ${ }^{14}$ 
Rāmānuja's argument on duty unfolds in his commentaries in four moves. First, actions are inescapable for an embodied soul, Rāmānuja explains. Second, the soul, in addition to inert Prakrti, is also an agent of action whose agency comes from God. Third, given the soul's nature as a complementary agent, it is accountable for its actions; this means the Lord favors those who are virtuous and vice versa. ${ }^{15}$ Finally, as we are responsible for our actions, we must be able to distinguish virtuous acts from non-virtuous ones, proper acts from improper ones (more on this below). Arjuna's desire to renounce his warrior-duty is not the only challenge Rāmānuja is trying to address. He also seems invested in addressing another challenge: the argument that I am not responsible for my actions and all agency rests solely with nature. In this construction, no actions are good or bad, proper or improper.

In his commentary on the Brahma-Sütras, Rāmānuja explains that the problem with sāmkhya is that it cleaves the body from the soul in matters of agency. "When the soul realizes the difference between itself and the Prakṛti, it attains Liberation," so the Sāṃkhyas claim. ${ }^{16}$ For even though the Sāmkhyas acknowledge the existence of souls, souls are incapable of doing work and all work is done by the gross elements. ${ }^{17}$ In response, Rāmānuja argues that scriptural injunctions - to desire Brahman, perform sacrifices, and fulfill svadharma - show that the soul is an agent. An intelligent self alone can have desires and inert Prakrti cannot, he writes in the $\hat{S}^{\prime} \bar{i}$ Bhāsya. ${ }^{18}$ Hence, scriptures prompt a person who desires certain things to perform certain acts. While scriptures also say that Kṛșna is the antaryāmin or "inner controller" (e.g., see Rāmānuja's commentary on Gìtā 7.7, 9.4, and 18.61), responsibility for the action is not cleaved from the soul. The Lord does not make a person do good or evil but rather acts as an amplifier. The Lord aids the good resolve of virtuous people and gives evildoers great delight in their actions. ${ }^{19}$ Since we must act, and are responsible for our actions, the type of our actions must be proper. Given the value of proper acts, Rāmānuja takes the trouble to define what constitute proper acts. In Rāmānuja's schema, detached actions are proper acts because they (a) are enjoined by scripture, (b) lead to merit, and (c) provide aid for meditation on Brahman. ${ }^{20}$ Rāmānuja, then, finds merit in the performance of proper acts.

Merit was a dominant issue for Martin Luther too and shaped his teachings on good works. ${ }^{21}$ As Timothy Wengert notes, Luther was trying to promote a "new, down-to-earth piety to all Christians" in response to those who argued that Luther's position implied that Christians were "free from the obligation to perform any good works at all."22 Luther's purvapakhsa is a religious world occupied with praying, fasting, holy days, almsgiving, acquiring indulgences, pilgrimages, and a host of other recommended or required works. ${ }^{23}$ For a medieval Christian, the development of piety was important. Piety was identified by the performance of Christian virtues ('you will know a tree by its fruits'). However, failure in piety was a fact of life and so mechanisms for remission from the effects of un-virtuous acts were in place. The sale of indulgences was one such option available to a medieval christian. Works mattered and remission could be earned. Luther's response to the argument for merit - that salvation was by faith and not works - posed its own challenge to his listeners and readers. What is to be of a virtuous life? Does it even matter? Should I be virtuous? If so, how? Given that my soul is saved outside the necessity of my acts, how should I live? Luther responds to these concerns. 
First, he argues that grace does not negate a virtuous life; this is because the gift of grace does not negate the word of God to do certain things and not do certain things. God has already decreed the performance of actions. Where Rāmānuja pegs the inescapability of actions in embodiment, Luther pegs it in God's word. Where Rāmānuja plants the fruits of work in the shared agency of the soul, Luther grounds the propriety of acts in the keeping of God's commandments. God commands and forbids. God has already decreed two types of acts: prescribed ones and proscribed ones. Good works do not save and salvation is an unearned gift. Yet, some acts are prescribed and others are proscribed by God. Recognizing salvation as a gift negates neither this distinction among acts nor the need to act according to this distinction. Rather, scripture tells us we must keep God's commandments (Matt 19.17). Scripture is, Luther asserts, rather clear about not just the need to keep God's commandments but also the content of God's commandments. He writes in his introduction to his treatise on good works:

It should be known that, first of all, that no good works exist other than those that God has commanded, just as there is no sin other than what God has forbidden. Whoever wishes to recognize and perform good works need only learn God's commandments. Accordingly, Christ says in Matt. 19: "If you wish to enter life, keep the commandments." And when the young man asks in Matt. 19 what he has to do to be saved, Christ holds up to him the Ten Commandments and nothing else. Therefore, we must learn to distinguish among good works from God's commandments and not from the appearance, magnitude, or quantity of the deeds themselves or from human opinion, laws, or approaches. ${ }^{24}$
A virtuous life of good works can fulfill the desire to enter eternal life. Good works should be practiced, if the questions is, what am I to do to enter life? Further, scripture does not leave the content of "good works" undefined. Rather, scripture gives us the Ten Commandments that Christ recommended to the young man in Matthew 19 as the sole code of conduct that is prescribed. In making this argument, Luther is following the medieval practice of using the Decalogue as a code of conduct. ${ }^{25}$ Finally, not all works that seem good are 'created' equal. The source of a prescribed action defines its value as a good work. For Luther, God-created works, like the Decalogue, are good and obligated to a Christian precisely due to the fact that these works are commanded by (and so 'created' by the word of) the God in whom she places her trust for, and from whom she receives, her salvation. Human-decreed works, like pilgrimages, clerical celibacy, and other secular and ecclesiastical laws that enjoin good works are useful in a secondary sense and can help those Christians who are not voluntarily inclined to keep God's commandments.

Second, faith in Christ - which Luther describes as the "foremost and noblest good work" ${ }^{26}$ - motivates a person to act in ways that are pleasing to God. Such a person is confident and peaceful in the knowledge that her actions are pleasing to her God. At issue for Luther is the degree of confidence that a person can have in the value of her acts before God. Only faith in being saved freely gives one confidence to act freely. Without such faith, one is left trying to act better and better never knowing whether all this effort is enough to save the soul. When salvation is free from the weight of right choices, one is free to act simply and boldly in the assurance of salvation. 


\section{Should I Act? The Lord Saves}

In light of their comparable contexts where the value and necessity of works were under debate - Rāmānuja and Luther assert that proper acts (Rāmānuja) or good works (Luther) are not optional. To make their respective case, Rāmānuja draws on sāmphya ideas on prakrti and Luther proposes that obedience to God is the outcome of a life thoroughly shaped by faith in the work of Christ. Further, and consequently, since works are not to be considered optional, the proper way to act is to act in ways that are informed by scripture and shaped by grace. The shape of proper acts or good works constitutes the second point of contact between Rāmānuja and Luther.

It seems that the reason why Rāmānuja and Luther can both emphasize proper acts on the one hand and make them devotional in intent rather than salvific in effect on the other hand is a shared instinct about the way in which a person is saved. The comparable forms of their respective theologies of mokșa (or, mokșalogies) are best understood as the logical outcome of their shared interest in placing a gracious God at the heart of mokșa.

Rāmānuja gives high regard to prescribed actions and does not promote their abandonment. He affirms the importance of actions like rituals, sacrifices, oblations, control of breathing, etc. for those seeking ends in the material world. " "[O]ne should not relinquish one's works [or duties]," he writes. ${ }^{28}$ He clarifies that when Kṛșna instructs Arjuna to abandon all of his duties in order to seek God alone, the lesson is not to relinquish all devotional duties but to relinquish one's sense of agency and attachments to the fruits of actions. ${ }^{29}$ Those actions are proper that are done with proper knowledge, which refers to knowledge of the real nature of the self and of its claims to sole agency. Knowledge of this real nature should lead one to act free from the desire for the fruits of such actions. Detached actions allow the self to experience itself as "It really is." ${ }^{30}$ Such actions, however, only seem to take you so far. Attainment of Brahman remains an act of grace. As Kṛșna tells Arjuna in the Gitā: one who worships Me with his own duty, performed in the proper way, attaints Myself by My grace (18:46).

Rāmānuja is insistent that salvation or mokșa ultimately resides in Krṣna and is a gift of the Lord's grace. This is partly because Rāmānuja's theology seems to reorient the locus of liberation. Where a Vedāntic (and Advaitic) view held that release can be achieved by proper knowledge, Rāmānuja's theology poses devotion as the means to deliverance. In his construction, the removal of ignorance in a self-aware self is not the form of salvation. Rather, as C. J. Bartley notes, the achievement of salvation is "conceived of as relationship with Viṣnu." ${ }^{31}$ Liberation is open to all whose exclusive goal is Vișnu. Extending this argument, Rāmānuja explains, "You will live in Me alone immediately after focusing your mind on Me by forming the conviction that I alone am the supreme object to be attained." ${ }^{32}$ A focus on Krșna alone does not mean the relinquishing of all duties. Rather, it means the relinquishing "only of the sense of agency and the fruits" of all duties, which are now all to be done in a devotional mode and as such directed toward God who is the source of my release from all obstructions to mokșa.33 Detached actions, or actions done without regard for their merit but with regard for their obligatory nature, then become the proper way to act in the world.

In similar fashion, Luther suggests: since salvation is through the work of God in Christ, good works are detached from claims of merit that can be viewed as earning justification. A reliance on works can only frighten us, but we 
can find comfort in God's grace. ${ }^{34}$ Good works matter. Since not all are inclined to voluntarily to good works, secular and ecclesiastical laws regarding good works serve both as reminders of the importance of good works and catalysis for the performance of good works. Faith does not negate good works. Rather, faith in God for one's salvation is the source and "master artisan" or "captain" of good works. Faith both shapes good works and directs them (toward God)..$^{35}$ While a righteous person needs no law, those who are young or immature in faith need these guiderails. ${ }^{36}$ Yet, even for a righteous person good works can take her only so far. Good works do not manufacture faith, Luther writes, any more than they earn mercy. ${ }^{37}$ Since original sin is by nature innate in all, no amount of good works in themselves can root out the effect of sin, death.

The inability of good works to save from death is a function partly of the source of goodness in works. "Many good works" are contained in the commandments, Luther offers, "but they are not good in and of themselves but only when they are done in faith [that God saves in Christ] and with confidence in divine benevolence [that we are saved without regard for merit]. ${ }^{38}$ Faith in Christ gives good works their goodness. ${ }^{39}$ Good works draw their goodness from God's works and words. "Good should not be judged and evaluated," Luther writes regarding the value of the Sermon on the Mount, "on the basis of our suppositions but on the basis of what God says and pronounces to be good." ${ }^{40}$ Good works draw their goodness from God in two broad senses.

In one sense, faith in Christ shapes works in certain ways. Good works are given content by the work of Christ. We know certain works are good and right because Christ did them in certain ways. The classic examples Luther relies on to explain the content-giving mode of Christ's work are the recitation of the Lord's prayer, the performance of baptism and last supper, and the keeping of the ten commandments. Each of these actions was done by Christ in a certain way and as such are to be repeated regularly by Christians. In another sense, how a Christian interprets Christ shapes her understanding of works. Here Luther is speaking of proper interpretations of Christ.

Luther proposes that there are two modes of understanding the life and work of Christ. In the first and common mode, Christ is seen as an exemplar of the types of work recommended to Christians. In this mode, Christ is "an example that is presented ... which you [Christians] should follow and imitate." ${ }^{" 11}$ This mode of interpretation is a lower way of understanding Christ. The higher mode of understanding Christ is to "accept and recognize him as a gift" and the "chief article and foundation of the gospel" is to recognize Christ as the saving gift before making him an example. ${ }^{42}$ Understanding the content of and committing to the performance of good works is a Christ-based activity. The works that are good for Christians are given both their meaning and content by the bimodal interpretation of Christ.

Proper works matter to both Rāmānuja and Luther. Proper works are also rewarding for both teachers. However, proper works matter only to the extent they are grounded in the work of the Lord. Finally, we turn to the third point of contact between their theologies when we ask: how do I act properly? How can I know which work is proper? Differently put, how do I discern among types of acts?

\section{What Should I Do? Works That Matter}

Rāmānuja and Luther suggest that those works are to be considered proper and good that are informed by the work of God. Sacred 
scripture is the source of this jñãya. Scripture reveals that proper works do not accrue merit nor produce liberation. They help humans live a life of true surrender to God in the comfort that God saves. Knowledge of God's work helps separate proper works from improper ones. Following the Vedās, Rāmānuja distinguishes between three types of duties that are to be considered appropriate and necessary. There are obligatory duties, duties that are occasionally obligatory, and duties performed for desired ends. Karma Yoga, in Rāmānuja's theology, consists in not relinquishing all these duties but rather in performing them without attachment to their fruits. ${ }^{43}$

Rāmānuja argues that toward the performance of works or duties one can adopt three types of attitude: the non-performance of work, the cessation of work already begun, and detached actions. Rejecting the first two approaches to the question of whether works are to be performed, he writes that it is only through "actions done without attachment to the fruits and by way of worshipping the Supreme Person" that a person receives liberation. ${ }^{44}$ Proper works or works done in bhakti nurture release or mokșa. The relinquishing of duties creates obstacles to one's salvation. Rāmānuja writes of the relationship between the performance of duties and the attainment of the Lord:

In this way, the crowning development has been told starting from the disinterested performance of periodical and occasional rites suitable for the various stations and stages of life, which are to be performed to propitiate the Supreme Person. [Further,] even for actions meant for attaining desired objects (Kāmya-karmas) the crowning stage is the same as for these described above, provided they too are done not for fulfilling one's desires but as offerings to propitiate the Supreme Person. ${ }^{45}$

In similar fashion, Luther distinguishes between 'necessary' works and 'unnecessary' works. Not all works are good. Faith gives good works their goodness. Further, not all works that are done in faith are necessary. Since it is hard enough to keep the commandments God has enjoined, a Christian should have no need, nor would she have the time, to chase secular and ecclesiastical good works. Luther explains in his conclusion to the treatise on good works, "Since people have their hands full with obeying the commandments God has given, even if they used all their strength and neglected everything else, and still cannot do all these good works, why should people look for other works that are neither necessary nor commanded and ignore the ones that are?"46 The source from which good works are so enjoined adjudicates whether a good work is necessary. As a consequence of this logic, proper or good works represent the effect of God's work (in Christ) on human acts.

In conclusion, we can return to our opening question - what is the place of my actions in God's salvific saga? - and surmise an answer drawn from the respective theologies of Rāmānuja and Luther. Due to a shared theological claim that mokșa is a gift that shapes the behavior of recipient and seeker alike, surrender to God has a necessary counterpart in the realm of actions: the performance of proper acts, proper as such due to their genesis and grounding in scripture. Grace never unmoors one from obligations because both Rāmānuja and Luther hold that scriptures enjoin certain actions and forbid others. Like the farmer who tends seeds in order to enjoy the best chance for a healthy and fruitful crop, a seeker of grace tends to good deeds (and surrenders her work to God) in order to enjoy union with God. 
In conclusion, then, Rāmānuja's and Luther's discourses on proper (and, ipso facto, rewarding) acts present us with a shared

\section{Notes}

${ }^{1}$ This date assumes the earlier birthdate ascribed to Rāmānuja by the Śrīvaiṣnava tradition. On the traditional year of Rāmānuja's birth, see Tapasyananda, Bhakti Schools of Vedāntda, 1. Ranjeeta Dutta agrees with this date (Dutta, From Hagiographies to Biographies, 12-13). For a different year of birth, see Carman, The Theology of Rāmānuja, 27.

${ }^{2}$ John Carman and Vasudha Narayanan have argued for the provenance of prapatti in the authentic works of Rāmānuja (Carman and Narayanan, The Tamil Veda, 42. See also Narayanan, The Way and the Goal). For the purpose of this paper, however, the provenance of prapatti is a tangential matter. Both the northern and southern schools of the Śrivvaișnava tradition take grace seriously and see it as the primary means of liberation. (On the primacy of 'divine grace,' see also Lester, "Rāmānuja and Śrī-Vaișnavism") That this dependence on the Lord for liberation is not a negation of complementary obligations (regarding one's proper works or dharma) is also evident in the works unambiguously authored by Rāmānuja. As Carman has succinctly put it, "For neither group does the doctrine of grace lead to an antinomian lifestyle." (Carman, "Śrī Vaișnavas," 8728)

${ }^{3}$ In 1953, J. Calvin Keene published "Rāmānuja, The Hindu Augustine" in The Journal of Bible and Religion (now the Journal of the American Academy of Religion). I was unaware of Keene's thesis prior to my own framing of Luther as a Christian Rāmānuja. However, both projects share certain impulses: they show how similar questions have led to similar answers across religious traditions. They identify points of contact between Hindu and Christian theologies. The projects also differ in certain ways. While I focus on the importance of works in the respective mokșalogies (or soteriologies) of Rāmānuja and Luther, Keene primarily compares Augustine and Rāmānuja on the nature of God, the nature of human, and the relation of God to the world and to humans. refrain: do good works as scripture enjoins; surrender this work to God; receive grace and find liberation.

Keene's third section on salvation seems to track my commentary on salvation. However, where Keene focusses on the role of God in salvation - the essay ends with the debate between bhakti and prapatti within the northern and southern schools - I have focused on the role of human responsibility and the importance of proper works in salvation.

${ }^{4}$ Otto, India's Religion of Grace.

${ }^{5}$ Overzee, The Body Divine.

${ }^{6}$ Tsoukalas, Krșna and Christ and Dunn, A. J. Appasamy and his Reading of Rāmānuja.

${ }^{7}$ Prasad, Rāmānuja and Hegel.

${ }^{8}$ Kumar, Rāmānuja and Bowne.

${ }^{9}$ Sydnor, Rāmānuja and Schleiermacher.

${ }^{10}$ Rāmānuja, Gittā Bhāșya, 592 (Gïtā, 19.59).

${ }^{11}$ Dasgupta, A History of Indian Philosophy, Vol. II, 516.

${ }^{12}$ Malinar, The Bhagavadgittā, 80.

${ }_{13}$ Monier-Williams, Sanskrit-English Dictionary, 510.

${ }^{14}$ Zaehner, The Bhagavad-Gittā, 184.

${ }^{15}$ Rāmānuja, Śrī Bhāṣya, 295 (2.3.41).

${ }^{16}$ Ibid., 243 (2.2.1).

${ }^{17}$ Dasgupta, A History of Indian Philosophy, Vol. III, 527.

${ }^{18}$ Rāmānuja, Śrī Bhāṣya, 292 (2.3.33).

${ }^{19}$ Ibid., 295 (2.3.41).

${ }^{20}$ Ibid., 435 (3.4.51).

${ }^{21}$ Luther, "Treatise on Good Works" (1520).

${ }^{22}$ Wengert, The Annotated Luther, 257-259.

${ }^{23}$ Ibid., 259.

${ }^{24}$ Ibid., 267.

25 See, for instance, Smith, The Ten Commandments and Desplenter et al. (eds.), The Ten Commandments in Medieval and Early Modern Culture.

${ }^{26}$ Luther, "Good Works," in Wengert, The Annotated Luther, 267.

${ }^{27}$ Rāmānuja, Gìtā Bhāṣya, 181 (Gîtāa 4.31).

${ }^{28}$ Ibid., 584 (Gitāa, 18.48).

${ }^{29}$ Ibid., 598 (Gïtā, 18.66).

${ }^{30}$ Ibid., 587 (Gitā, 18.53)

${ }^{31}$ Bartley, The Theology of Rāmānuja, 78, 156. 
${ }^{32}$ Rāmānuja, Gìtā Bhāṣya, 401 (Gītā, 12.8).

${ }^{33}$ Ibid., 598-599 (Gìtā, 18.66).

${ }^{34}$ Luther, "Good Works," in Wengert, The Annotated Luther, 284.

${ }^{35}$ Ibid., 280.

${ }^{36}$ Ibid., 281-282.

${ }^{37}$ Ibid., 285.

${ }^{38}$ Ibid., 302.

${ }^{39}$ Ibid., 268.

${ }^{40}$ Pelikan, Luther's Works 21: 263.

${ }^{41}$ Luther, "What to Expect," in Lull, Basic Theological Writings, 94.

${ }^{42}$ Ibid., 95.

43 Rāmānuja, Gìtā Bhāṣya, 17. See also Rāmānuja's commentary on Gītā 18:56 (Rāmānuja, Gìtā Bhāṣya, 590).

${ }^{44}$ Ibid., 121 (Gìtā, 3.4).

${ }^{45}$ Ibid., 589 (Gìtā, 18.55).

${ }^{46}$ Luther, "Good Works," in Wengert, The Annotated Luther, 366 (emphasis added).

\section{References}

Bartley, C. J. 2002. The Theology of Rāmānuja: Realism and Religion. London: Routledge. DOI: https://doi.org/10.4324/9781315028828

Carman, John B. 1974. The Theology of Rāmānuja: An Essay in Interreligious Understanding. New Haven: Yale University Press. . 2005. "Śrī Vaiṣnavas." In Encyclopedia of Religion, edited by Lindsay Jones. Vol. 13, second edition. Detroit: Macmillan Reference: 8727-8729.

and Vasudha Narayanan. 1989. The Tamil Veda: Pillān's Interpretation of the Tiruvāymoli. Chicago: The University of Chicago Press.

Dasgupta, Surendranath. 2010 (Reprint). A History of Indian Philosophy, Vol. II. Delhi: Motilal Banarsidass Publishers (First Indian Delhi Edition, 1975).

. 2007 (Reprint). A History of Indian Philosophy, Vol. III. Delhi: Motilal Banarsidass Publishers (First Indian Delhi Edition, 1975).

Desplenter, Youri, Jürgen Pieters, and Walter Melion (editors). 2017. The Ten Commandments in Medieval and Early Modern Culture. Leiden: Brill. DOI: https://doi.org/10.1163/9789004325777
Dunn, Brian Philip. 2016. A. J. Appasamy and his Reading of Rāmānuja: A Comparative Study in Divine Embodiment. Oxford: Oxford University Press. DOI: https://doi.org/10.1093 /acprof:oso/9780198791416.001.0001

Dutta, Ranjeeta. 2014. From Hagiographies to Biographies: Rāmānuja in Tradition and History. New Delhi: Oxford University Press. DOI: $\quad$ https://doi.org/10.1093/acprof:oso $\angle 9780198092292.003 .0006$

Keene, Calvin J. 1953. "Rāmānuja, the Hindu Augustine." In Journal of Bible and Religion, Vol. 21, No.1 (January), 3-8.

Kumar, Frederick L. 1962. Rāmānuja and Bowne: A Study in Comparative Philosophy. Bombay: Chetana.

Lester, Robert C. 1966. Rāmānuja and ŚrīVaiṣnavism: The Concept of Prapatti." In History of Religions, Vol. 5, No. 2. Chicago: The University of Chicago Press: 266-282.

Lull, Timothy F (editor). 2005. Martin Luther's Basic Theological Writings. Minneapolis: Fortress Press. DOI: https://doi.org/10.2307/j. ctt22h6s70

Luther, Martin. 1520. "Treatise on Good Works." Translated by Timothy Wengert in The Annotated Luther, Volume 1: The Roots of Reform. Minneapolis: Fortress Press (2015). DOI: https://doi.org/10.2307/j.ctt13wwwwt 1521. "A Brief Instruction on What to Look for and Expect in the Gospels." In Martin

Luther's Basic Theological Writings, edited by Timothy F. Lull. Minneapolis: Fortress Press (2005). DOI: https://doi.org/10.2307/ j.ctt22h6s70.16

Malinar, Angelika. 2007. The Bhagavadgitā: Doctrines and contexts. Cambridge: Cambridge University Press. DOI: https://doi.org/10.1017/CBO9780511488290

Monier-Williams, Monier. 2005. A Sanskrit-English Dictionary, Etymologically and Philologically Arranged with special reference to Cognate Indo-European Languages. Delhi: Motilal Banarsidass (first edition published by Oxford university Press, 1899).

Narayanan, Vasudha. 1987. The Way and the Goal: Expressions of Devotion in the Early Śri 
Vaișnava Tradition. Washington D.C.: Institute of Vaishnava Studies and Center for the Study of World Religion, Harvard University. Otto, Rudolf. 1930. India's Religion of Grace and Christianity compared and Contrasted. Translated by Frank H. Foster. New York: The MacMillan Company.

Overzee, Anne Hunt. 1992. The Body Divine: The symbol of the body in the works of Teilhard de Chardin and Rāmānuja. Cambridge: Cambridge University Press.

Pelikan, Jaroslav (editor). 1956. Luther's Works, Volume 21, The Sermon on the Mount (Sermons) and The Magnificat. St. Louis: Concordia Publishing House.

Prasad, Ram. 1983. Rāmānuja and Hegel: A Comparative Study. Classical Publishing Company.

Rāmānuja. $11^{\text {th }}$ c. CE. Śrïbhāṣya. Translated by Swami Vireswarananda and Swami Adidevananda in Brahma-Sūtras Śrī-Bhāṣya: With text, English rendering, Comments according to Śrī Bhāṣya of Śrī Rāmānuja. Kolkata: Advaita Ashrama (2003). $12^{\text {th }}$ c. CE. Bhagavadgītābhāṣya. Translated by Svāmī Ādidevānanda in Śrī Rāmānuja Gìtā
Bhāṣya: With Text in Devanagari \& English Rendering, and Index of First Lines of Verses. Mylapore: Sri Ramakrishna Math (1991).

Smith. Lesley J. 2014. The Ten Commandments: Interpreting the Bible in the Medieval World. Leiden: Brill.

Sydnor, Jon Paul. 2011. Rāmānuja and Schleiermacher: Toward a Constructive Comparative Theology. Eugene: Pickwick Publications.

Svāmī Tapasyānanda. 1990. Bhakti Schools of Vedānta: Lives and Philosophies of Rāmānuja, Nimbārka, Madhva, Vallabha and Caitanya. Mylapore: Sri Ramakrishna Math.

Tsoukalas, Steven. 2006. Krșna and Christ: BodyDivine Relation in the Thought of Sankara, Rāmānuja, and Classical Christian Orthodoxy. Milton Keyes: Paternoster.

Wengert, Timothy (translator). 2015. The Annotated Luther, Volume 1: The Roots of Reform. DOI: https://doi.org/10.2307/ j.ctt13wwwmp Minneapolis: Fortress Press. Zaehner, R.C. 1969. The Bhagavad-Gitā, with a commentary based on the original sources. London: Oxford University Press. 